\title{
Studies on the Hypothalamo-Hypophseal Control of the Thyroid
}

\author{
By
}

\author{
Iwao WATANABE \\ Department of Surgery, Fukushima Medical College, Fukushima, Japan. (Director : Prof. S. Endo)
}

The present study was made to evaluate the hypothalamo-hypophyseal control of thyroid.

The results obtained were as follows :

In euthyroid rabbits, injected with ${ }^{131} \mathrm{I}$, the posterior pituitary had more affinity for ${ }^{131} \mathrm{I}$ than that in median eminence and anterior pituitary.

In hyperthyroidism, produced by the administration of TSH and thyroid hormone, ${ }^{131} \mathrm{I}$ uptake in these tissues was remarkably increased. On the contrary, in hypothyroidism, by the thyroidectomy and administration of MTU of cortisone, concentration of the ${ }^{131} \mathrm{I}$ in these tissues was significantly reduced.

As to the hypothalamic neurosecretory function and TSH secretion, in hyperthyroidism, these functions were inhibited, while they were stimulated in hypothyroidism.

These results revealed that the sites where ${ }^{131} \mathrm{I}$ was concentrated, corresponded to regions of the neurosecretory system, and also that the concentration of ${ }^{131} \mathrm{I}$ by the posterior pituitary and median eminence was associated with neurosecretory phenomena. This may be related to the functional control of the TSH secretion by the anterior pituitary.

\section{Clinical Studies on the Adrenocortical Function : with Emphasis on the Response of Plasma 17-Hydroxycorticosteroids Level to ACTH}

\author{
II. Adrenocortical Reserve Capacity During Long-term Corticoid Therapy \\ By \\ Naoji SHIBUKAWA \\ Department of Internal Medicine, Tohoku University School of Medicine, Sendai \\ (Director, Prof. Tatuo TORIKAI)
}

In treatment with adrenal glucocorticoids, the side-effect requiring strictest attention is a suppression of adrenocortical function. With the aim of estimating the reserve capacity of the adrenal cortex during prolonged corticoid therapy, ACTH test were performed in 15 patients who had received continuons corticoid therapy (group A) and 6 patients who had received intermittent therapy, giving corticoid only 3 4 days in the week (group B). Besides, in 5 cases who apparently showed secondary adrenocortical hypofunction during continuous corticoid therapy, ACTH-Z 40 I.U. were daily administered on 5 7 consective days to reactivate the decreased function of adrenal cortex.

1) In 9 of the 12 patients who had received long-term continuous corticoid therapy, the plasma 
17-OHCS response to the ACTH test was markedly decreased, but remained within normal limits in the other 3, who showed seriously deteriorated general conditions and were suffering from psychic or somatic stress.

2) In 12 cases of group A excepting the 3 cases serious deterioration of general condition, a significant negative correlation of response to ACTH with the duration and total dosis of corticoid administration could be established. That is with lengthening of the administration and the inclease of total dosis, the response was found enfeebled. Within the range of dosage used in this study (not less than $17 \mathrm{mg}$ daily in prednisolone equivalent), however, no correlation could be observed between the mean daily dosis and the response to ACTH.

3) In 5 patients of the group A, the suppressed adrenocortical function was reactivated by the administration of ACTH-Z 40 I.U. for $3 \sim 5$ concecutive days.

4) In 4 of the 6 cases of group B, the response to ACTH showed results within normal limits and in the other 2 cases also the response was little anomaly.

\title{
Inhibitory Effect of $\beta$-PIPH on Some Enzymic Activities Related to Vitamin $B_{6}$
}

\author{
By
}

\author{
Kōzō YAMADA, Shunji SAWAKI, Chuya YAZAKI, \\ Masaru HAYASHI and Akira FUKUMURA \\ Department of Internal Medicine, Faculty of Medicine, Nagoya University, Nagoya
}

Inhibition of some vitamin $\mathrm{B}_{6}$ enzymes by carbonyl reagents, metal-chelating agents and phenylalanine derivatives has been reported. Recently, monamine oxidase inhibition by $\beta$-phenyl-isopropylhydrazine has also been demonstrated, but it is not clear whether monamine oxidase is related to vitamin $\mathrm{B}_{6}$ enzyme and vitamin $\mathrm{B}_{2}$ enzyme or not. In the present paper, we report on our studies, on the mechanism of inhibition of the tryptophanase (vitamin $\mathrm{B}_{6}$ enzyme) and $\mathrm{d}$-amino acid oxidase (vitamin $\mathrm{B}_{2}$ enzyme) by $\beta$-phenyl-isopropyl-hydrazine.

The results were as follows;

1) $\beta$-PIPH was found to be inhibitory on the tryptophanase, although it did not influence the inhibitory response on the d-amino acid oxidase.

2) Detailed study indicated that $\beta$-PIPH is a nonspecific, formally noncompetitive inhibitor of the tryptophanase.

3) This inhibition is achieved by the removal of cotryptophanase added to the system in vitro through nonenzymatic reaction with $\beta-\mathrm{PIPH}$.

4) This conclusion was strengthened by the preparation and characterization of the product of the reaction between pyridoxal and $\beta-\mathrm{PIPH}$, and its identification as a substituted pyridoxylidene- $\beta$ phenyl-isopropyl-hydrazine. 


\section{副腎皮質機能に関する臨床的研究 主として ACTH に対する血中 17-OHCS}

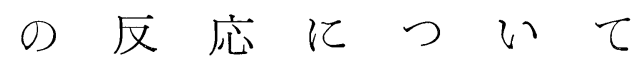

第 2 報 副腎皮質ステロイド剤を長期間投与した際の

副腎皮質予備能について

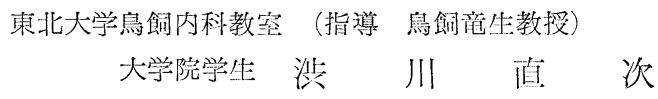

(炤和36年11月15日受付)

第 1 章 緒言

副緊皮質ホルモン療法に際し，最も注意すべき副作用の一つは下垂体副緊皮質機能の抑制である。

Ingle ら ${ }^{1}$ )の実験以来，副腎皮質ステロイド剤（以下ステロイドと咯す）長期間投与により副㹂皮質の萎縮 を来すととは周知の事実である。乙の原因について Sayers ${ }^{2}$ は は皮質物質が下垂体からの ACTH 分泌を抑 制する結果であると推論しており,その後の研究からも副篎皮質ホルモンの血中浱度が下垂体からの ACTH 分泌を調節する重要な因子であるととは，現在広く認められている。副腎皮質腫煬による Cushing 症候群 で対側副腎皮質の菱縮が認められる事実はこの説を裏づけるものであり，また Jailer 試験，及び先天性副 腎性器症候群のステロイド療法はこの理を応用したものである。

最近 Holub ら³ 副腎の菱縮及び下垂体中の ACTH 濃度の著明な低下を来たし, Stress に際しての ACTH 分泌が低下す るととを認めた。更に彼ら ${ }^{4}$ は Cortisone 治療を受けた剖検例について，下垂体中の ACTH 濃度と Cortisone 投与量との間には逆相関が認められたと述べている，然しある種の条件下では，ACTH の分泌調節 を血中副腎皮質ホルモン濃度のみによつては説明出来ない事実がありゔ，また一方副腎皮質からの糖質代謝 コルチコイド分泌はACTH による体液性支配の他に，神経性支配をも受けていると推定される成績が報 告されている( ${ }^{67)}$.

一方臨床面に於いては1948年 Hench が Cortisone を関節りウマチ患者に用いて劇的効果をおさめて以来， 各科領域に於いてその適応範囲は益々拡がりつつある。最近本剤は急速な進歩をとげ, Predonisolone, Methyl-prednisolone, Triamcinolone, 更に Dexamethasone と抗炎症作用の強力な合成剤が発見され，副 作用の一つである塩類蓄積作用の除去には成功したが，反面下垂体抑制作用は抗炎症作用に比例して強力と なり，ての 2 つ作用の分離は現在なお未解決の段階である。 また本剤はその薬理的性質上，多くの疾患に 対しては対症療法としての意義をもつに止まり，長期にわたる大量投与が澼けられない，ステロイドの長期 間投与中または投与中止後に，副腎皮質機能低下時と極めてょく似た症状または代謝異常を起し ${ }^{899) 10) 11) ， あ ~}$ るいは外科的手術及び感染等の Stress に際し副腎発症を起して死亡した例も報告されている ${ }^{12213) 14115)}$.

ステロイドを長期間投与した際の副腎皮質機能低下については，Forsham $ろ^{8)}$ が Cortisone 療法中尿中 17-KS 排泄量が低下するてとを見出して以来，多くの報告がなされているが，その詳細はなお不明な点が 多く，ステロイド投与中の皮質機能の検索は Dexamethasone の登場以前は困難であつた。 またステロイド

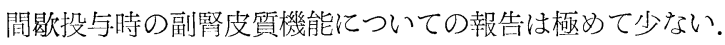


私はステロイドを長期間連続的に，また間歇的に投与した患者の副㙰皮質予備能について，主として血中 17-OHCS の ACTH 投与による反忘を指標として検索し，若干の知見を得たのでててに報告する.

\section{第 2 章 実験対象並びに方法}

\section{1) 実験対象}

当内科の入院㭧者で，ステロイド連日投与豲法を行なつたネフローゼ症候群 5 例, リウマチ性関節炎 3 例, リウマチ熱 2 例, リウマチ性肺線維症 1 例, Sarcoidosis 1 例, 未梢性顔面神経麻瘦 2 例, Banti 症候群 1 例 計15例，及びステロイド間傝投与療法を行なつたネフローゼ症侯群 6 例の総計 21 例を対象とした。

これらの中, リウマチ熱の 1 例はステロイド投与中にも拘らず $38^{\circ} \mathrm{C} \sim 39^{\circ} \mathrm{C}$ 発熱があり，ネフローゼ症候 群の 1 例は高度の浮腫及び腹水を件ない，またりウマチ性肺線維症の 1 例は高度の呼吸困難及び発熱を呈

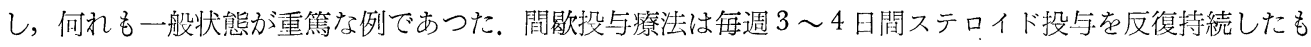
のである.

\section{2) 測定方法}

血中 17-OHCS，尿中 17-OHCS，尿中 17-KS 及び好酸球数の測定は笨 1 報 ${ }^{47}$ に述べたと同様の方法によ つた.

\section{3) 実験条件}

ステロイドとしては Prednisolone, Triamcinolone, Methyl-prednisolone 及び Dexamethasone t使用 した。投与量は総べて Prednisolone に換算し，その効力比率を Prednisolone : Triamcinolone : Methylprednisolone : Dexamethasone $=1: 5 / 4: 5 / 4: 7.5$ とした.

投与方法は 1 日量を $3 \sim 4$ 回に分割投与し，間歇投与法は全例においてまず連日投与法を22〜253日間実 施した後に引続き行なつた。

ACTH 試験は ACTH 25単位点滴静注法, または ACTH-Z 40単位筋注法の何れかを用い, 採血時間及 び採尿は第 1 報に述べたところに從い，連日投与例では投与中に施行し，間歇投与例では間歇期の前半に施 行した。なお血中 17-OHCS は点滴静注法では 3 時間値，笳注法では 4 時間值を中間值とし，それぞれの 6 時間值及び 8 時間值を終值とした。また Dexamethasone による連日投与中の 5 例では，ACTH-Z 40単 位筋注を 5 〜日問併用し，乙れによる血中 17-OHCS 值, 尿中 17-OHCS 值及び 17-KS 值の変動を追 求した。

\section{第 3 章 実 験 成 績}

\section{1) 連日投与例}

\section{a) $\mathrm{ACTH}$ 投与による血中 17-OHCS，尿中 17-OHCS，尿中 17-KS 及び好酸球数の変動}

(第 1 表. 第 $1 ， 2 ， 3 ， 4 ， 5 ， 6$ 図)

ステロイドを連日投与中の15例について，AGTH 試験を施行した際の血中 17-OHCS 值の変動を第 1 図 に示した. 長期 (3 週間以上) 投与例12例中 9 例では ACTH に対する反応が著明に低下しており，その 9 例中 6 例では終值が中間值より低く，山型の反応曲線を示した。また 1 例では中間值及び終值が共に前値よ り低く, 皮質予備能の欠如か推定された。長期投与例の残りの 3 例は ACTH に対し正常の反応を示した が，乙れは何れも一般状態が重篤な症例であつた。乙れらの平均值は第 2 図に示した如く，15例全体の平均 值は前值 $7.8 \gamma / \mathrm{dl}$ ，中間值 $15.7 \gamma / \mathrm{dl}$ ，終值 $15.9 \gamma / \mathrm{d} 1$ で正常以下であつた。 その中の長期投与例 12 例中, 一般状態重篤であつた 3 例の平均值は前值 $8.1 \gamma / \mathrm{dl}$, 中間值 $23.2 \gamma / \mathrm{d}$ l, 終值 $35.5 \gamma / \mathrm{d} l$ で正常であつたが, 他の 9 例の平均值は前值 $7.6 \mathrm{r} / \mathrm{dl}$ ，中間值 $12.6 \mathrm{r} / \mathrm{dl}$ ，終值 $7.8 \mathrm{r} / \mathrm{dl}$ で低值を示し，且つ山型の反応曲線を 示した。 またてれらの平均增加率は15例全体では中間值 $101.2 \%$ ，終值 $103.8 \%$ で，中間值と終值がほぼ等し かつた，長期投与例 12 例中，一般状態重篤であつた 3 例では中間值 $186.7 \%$, 終值 $338.2 \%$ で正常の增加率を 示したが，他の 9 例では中間值 $65.7 \%$ ，終值2.6\%と途中から再び減少してほぼ前値に戻つた。 


\begin{tabular}{|c|c|c|c|c|c|c|c|c|c|c|c|c|c|c|}
\hline \multirow{3}{*}{ 例 } & \multirow{3}{*}{$\begin{array}{l}\text { 年 } \\
\text { 令 }\end{array}$} & \multirow{3}{*}{ 突 } & \multicolumn{4}{|c|}{$\begin{array}{l}\text { 副㹂皮質 } \\
\text { ステロイド剂 }\end{array}$} & \multicolumn{8}{|c|}{$\begin{array}{l}\text { ACTH 試験 (ACTH 25学位点㵜静注文は } \\
\text { ACTH-Z 40单位筋注) }\end{array}$} \\
\hline & & & \multirow{2}{*}{$\begin{array}{c}+ \\
\text { 種 } \\
\text { 類 }\end{array}$} & \multirow{2}{*}{ (日) } & \multirow{2}{*}{$\begin{array}{c}\text { 総量** } \\
(\mathrm{mg})\end{array}$} & \multirow{2}{*}{$\mid \begin{array}{l}\text { 平均 } \\
1 \text { 日 } \\
\text { 量 } \\
(\mathrm{mg})\end{array}$} & \multirow{2}{*}{$\begin{array}{l}++ \\
\text { 方 } \\
\text { 法 }\end{array}$} & $\begin{array}{l}\text { 血中 } 17-\mathrm{OH} \\
\mathrm{CS}(\gamma / \mathrm{dl})\end{array}$ & \multicolumn{2}{|c|}{$\begin{array}{l}\text { 好酸球数 } \\
\left(ケ / \mathrm{mm}^{3}\right)\end{array}$} & \multicolumn{2}{|c|}{$\left|\begin{array}{c}\text { 尿中 } 17- \\
\text { OHCS } \\
\text { (mg/day) }\end{array}\right|$} & \multicolumn{2}{|c|}{$\begin{array}{l}\text { 䐂中 } 17- \\
\mathrm{KS} \\
\text { (mg/day) }\end{array}$} \\
\hline & & & & & & & & 前值|虫間 $\mid$ 終值 & 前数 & $\begin{array}{c}\text { 変動率 } \\
(\%)\end{array}$ & 対照 & $\begin{array}{l}\mathrm{AC}- \\
\mathrm{TH}\end{array}$ & 対照 & $\begin{array}{l}\mathrm{AC}- \\
\mathrm{TH}\end{array}$ \\
\hline 1 令 & 38 & ndrome & $\mathrm{D}$ & 9 & 345 & 38 & I.M. & 10.1 & & & & & & \\
\hline $2 \hat{\circ}$ & 43 & Facial Paralysis & $\mathrm{P}$ & 19 & 475 & 25 & I.M. & $10.5|21.3| 25.1 \mid$ & 133 & -15.8 & & & & \\
\hline 3 우 & 21 & hrotic Syndrome & $\mathrm{T}$ & 19 & 475 & 25 & I.M. & 26.9 & 34 & +23.5 & 0.3 & 0.8 & & \\
\hline $4 \hat{\delta}$ & 33 & atic Fever & $\mathrm{P}$ & 24 & 1050 & 44 & I.V. & \begin{tabular}{ll|l|l}
3.2 & 4.5 & 8.2
\end{tabular} & 147 & -78.9 & & & 7.2 & 6.6 \\
\hline $5 \hat{o}$ & 33 & Paralysis & $\mathrm{P}$ & 43 & 1290 & 30 & I.M. & \begin{tabular}{l|l|l|}
6.3 & 2.6 & 7.6
\end{tabular} & 16 & +100.0 & & & & \\
\hline 6 우 & 57 & matoid Arthritis & $\mathrm{D}$ & 53 & 1020 & 19 & I.V. & \begin{tabular}{l|l}
5.1 & 0
\end{tabular} & 34 & -64.7 & 0.3 & 0.3 & 4.1 & 3.7 \\
\hline $7 \hat{\circ}$ & 36 & Imatoid Arthritis & $\mathbf{P}$ & 55 & 1185 & 22 & I.V. & $8.714 .4 \mid 12.4$ & 137 & -66.3 & & & & \\
\hline 8 우 & 26 & $\mathrm{Sa}$ & $\mathrm{P}$ & 57 & 1005 & 18 & I.V. & \begin{tabular}{ll|l|l|l|}
9.4 & 16.2 & 13.7
\end{tabular} & 44 & -50.0 & & & & \\
\hline 9 우 & 30 & Rheumatic Fever* & P.M. & 60 & 1345 & 22 & I.V. & 11.220 .725 .0 & 91 & -70.6 & 0.8 & 1.6 & & \\
\hline 10 우 & 25 & Nephrotic Syndrome* & $\mathrm{D}$ & 61 & 1590 & 26 & I.V. & 6.821 .437 .0 & 76 & +63.2 & 1.3 & 2.4 & 3.2 & 5. \\
\hline 11 우 & 23 & Nephrotic Syndrome & $\mathrm{D}$ & 76 & 1823 & 24 & I.M. & \begin{tabular}{ll|l|l|l|l|}
6.9 & 13.3 & 9.5
\end{tabular} & & & & & & \\
\hline $12 \hat{\jmath}$ & 30 & Rheumatic Lungfibrosis* & $\mathrm{P}$ & 76 & 2385 & 31 & I.V. & . 6.327 .644 .5 & 99 & +22.2 & & & 3.9 & 6. \\
\hline 13 令 & 16 & Rheumatoid Arthritis & $\mathrm{D}$ & 78 & 1913 & 25 & I.V. & 10.619 .86 .5 & 44 & -59.3 & 0.3 & 0.5 & 5.0 & 5.5 \\
\hline $14 \hat{\jmath}$ & 23 & Nephrotic Syndrome & $\mathrm{P}$ & 94 & 3200 & 34 & I.M. & 11.421 .34 .5 & 41 & +242.0 & & & & \\
\hline $15 \uparrow$ & 16 & Nephrotic Syndrome & $\mathrm{P}$ & 22 & 2785 & 23 & I.V. & \begin{tabular}{|l|l|l|}
6.8 & 21.3 & 6.2 \\
\end{tabular} & 43 & +76.7 & 0.2 & 0.3 & 2.3 & 7.9 \\
\hline
\end{tabular}

* 一般状態重篤例

** 投与量は Prednisolone に換算

$+\quad \mathrm{D}=$ Dexamethasone, $\mathrm{P}=$ Prednisolone, $\mathrm{T}=$ Triamcinolone, $\mathrm{M}=$ Methyl-prednisolone,

+t I.V.=ACTH 25単位点滴静注, I.M.=ACTH-Z 40単位筋注

第 1 図副腎皮質ステロイド剤連日投与中の例にACTH を投与した際の血中17-OHCS值の変動

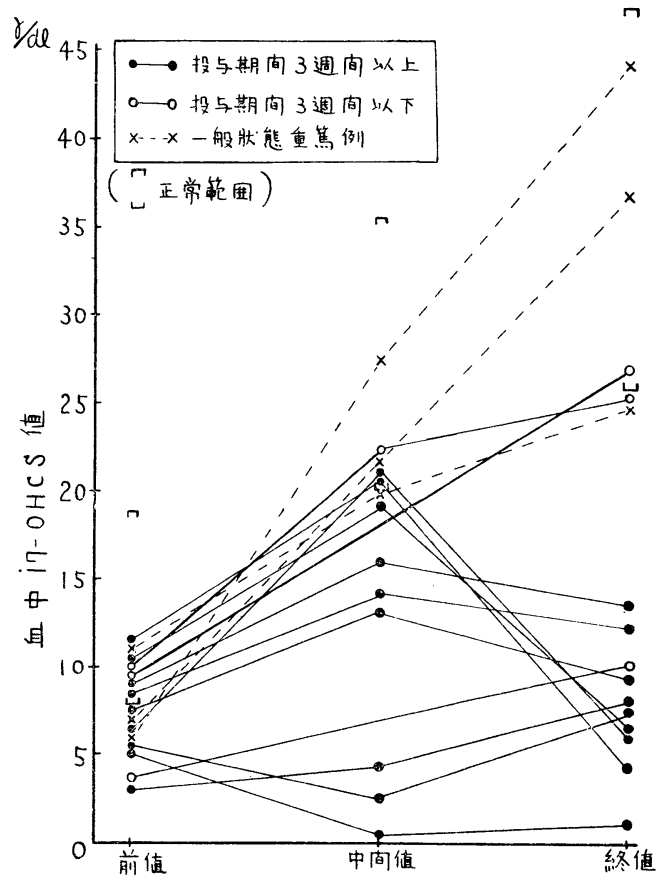

第 2 図副腎皮質ステロイド剂連日投与例及び間 歇投与例に ACTH を投与した際の血中 17-OHCS の平均值

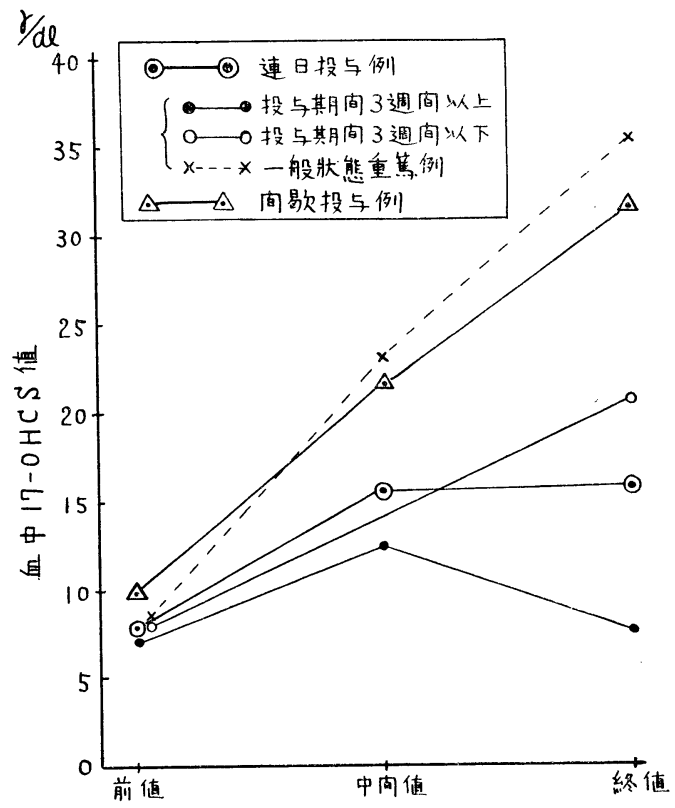


第 3 図 血中17-OHCSの前值とACTH 刺激值と の関係

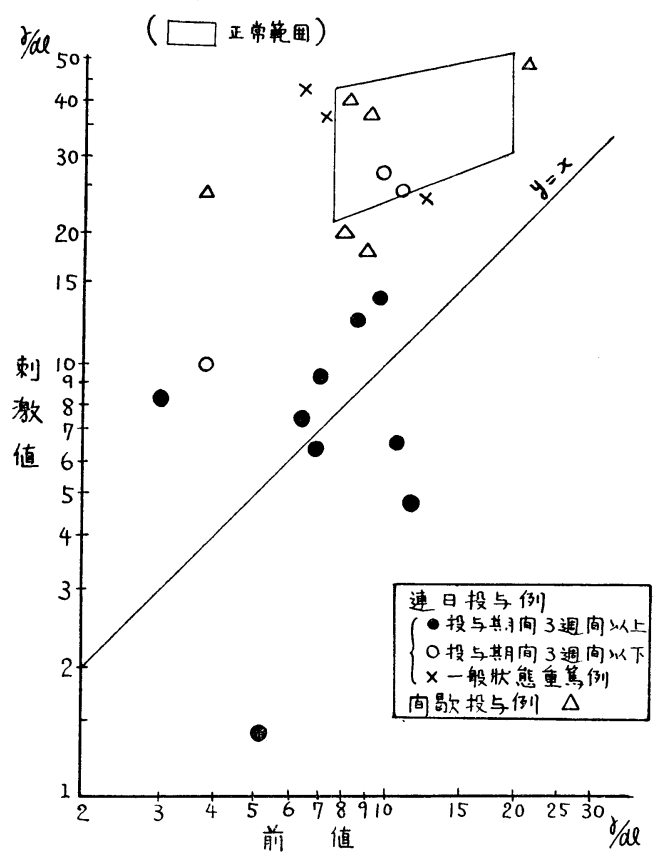

第5 図 副腎皮質ステロイド剤連日投与例に $\mathrm{ACTH}$ を 投与した際の好酸球変動率

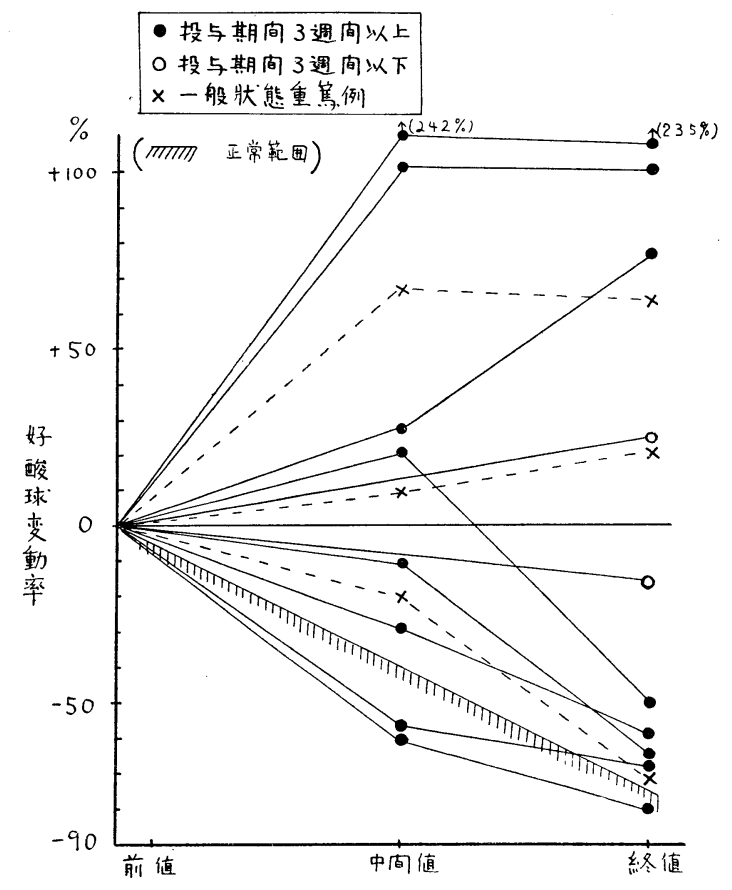

第 4 図 尿中 17-OHCS 排泄量の前值と ACTH 刺激值との関係

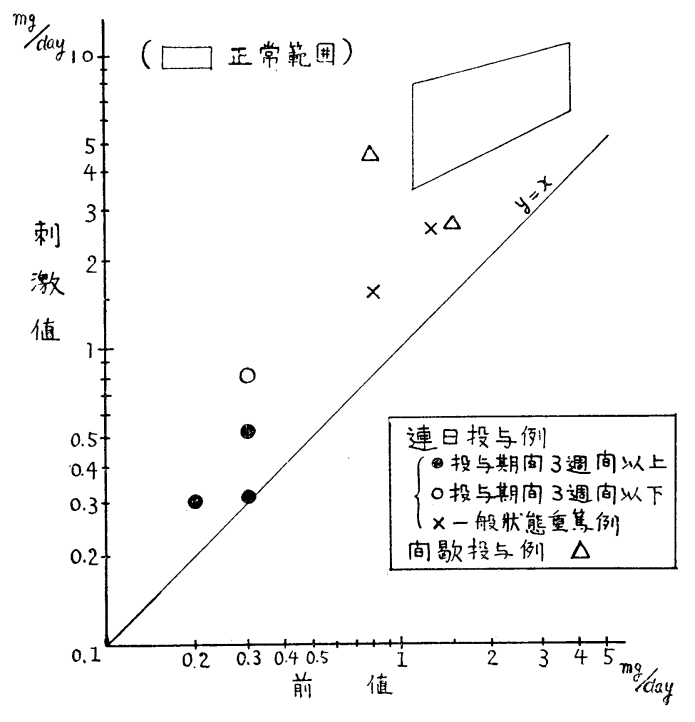

第 6 図 副腎皮質ステロイド剂連日投与例及び間 歇投与例に $\mathrm{ACTH}$ を投与した際の血中 17-OHCS変動率と好酸球変動率との関係

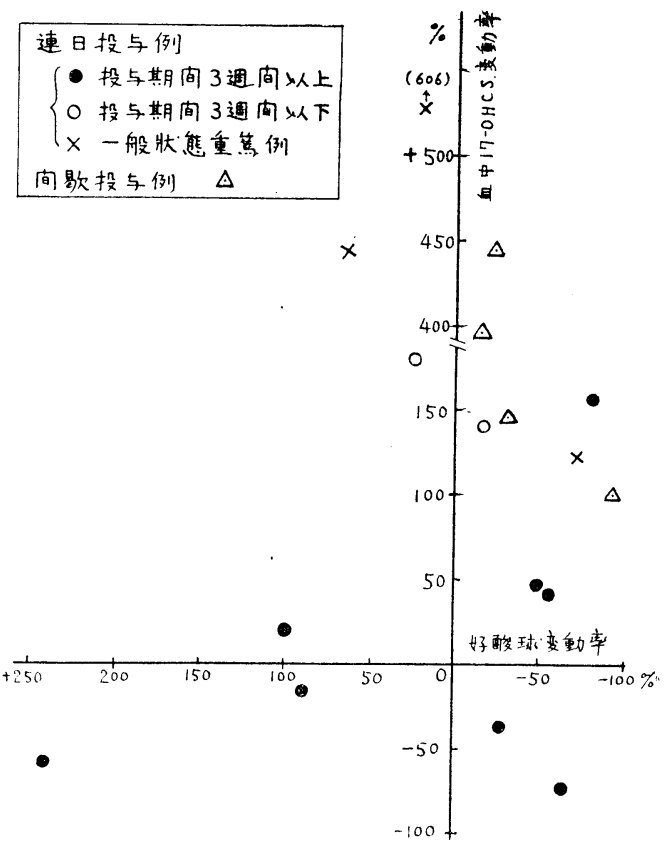


短期（3 週間以下）投与例の 3 例中 2 例では AGTH に対する反応が正常であつたが，残り 1 例では正常 以下であり，その平均値は第 2 図に示した如く，前优 $7.9 \gamma / \mathrm{dl}$, 終值 $20.7 \gamma / \mathrm{dl}$ で, 反応の軽度の低下がみ られた。 またとの平均增加率は，終值160.0\%であつた。

第 3 図は血中 17-OHCS の前值及び ACTH 刺激終值を対数目盛にとつたものである. 直線 $\mathrm{y}=\mathrm{x}$ 上の 点は前值と刺激值が等しいてとを示し，ての直線より上方の点は ACTH 投与により増加したととを示し， 下方の点は減少したてとを示す，従つてとの図から前值と刺激值との関係がー目瞭然となる. 即ち前值は15 例中 7 例では正常範囲内にあつたが，前值が正常でも全く反応を示さなかつた例があり，また逆に前值は正 常以下でもかなりの反応を示した例もあつて，前值と刺激值との間には一定の関係は認められなかつた。

ステロイド連日投与例に ACTH を投与した際の尿中 17-OHCS 排泄量の変動は, 第4 図に示した如く, 4 例では前值も ACTH に対する反応も低下していた。一般状態重篤であつた 2 例では前值の低下は軽度で あり，ACTH に対してもかなりの反応を示した。

$\mathrm{ACTH}$ 投与による好酸球数の変動率は第 5 図に示した如く，11例中 1 例を除いて他はすべて正常以下で あつた。 また ACTH 投与による好酸球数の変動率と血中 17-OHCS 值の変動率との間には, 第 6 図から 明らかな如く，何らの相関も認められなかつた。元来 ACTH による好酸球数の減少は副腎皮質ホルモン 分泌増加の間接的指標にすぎない. 且つステロイド投与中の患者では好酸球数は既に投与されたステロイド によつてある程度減少しているものである。ての様な点から，ステロイド投与中の例では ACTH 試験に好 酸球減少率を指標とするととは不適当と考えられる。

小括

1）ステロイド長期連日投与例における血 中 17-OHCS の ACTH に対する反応は， 一般状態重篤であつた 3 例を除いては著明に 低下しており，皮質予備能の減少が推定され i.

2) これらの例において，血中 17-OHCS の前值は必ずしも皮質予備能と平行するもの ではないてとが認められた。

3) ステロイド投与例では ACTH 試験に 際し血中 17-OHCS の反応と好酸球減少反応 との間には相関が認められなかつた。この場 合後者は $\mathrm{ACTH}$ 試験の指標としては不適当 と考光られた。

b) ACTH 投与による血中 17-OHCS 值の変 動とステロイド投与期間, 総投与量及 び平均 1 日投与量との関係

(第 1 表. 第 7，8，9図)

ステロイドを連日投与した15例について, $\mathrm{ACTH}$ 投与による血中 17-OHCS 変動值と 投与期間との関係を検索した成績は第 7 図に 示した如くである. 即ち一般状態重篤であつ た 3 例を除いては，投与期間が長い程反応は 低下する傾向を示し，投与期間と変動值との 間の相関係数 $\mathrm{r}=-0.7216$ であり, 危険率 1 \%以下で逆相関が認められた. 然し長期投与
第 7 図副腎皮質ステロイド剤連日投与例に ACTH危投与した際の血和17-OHCS 変動值と投与期間との関係

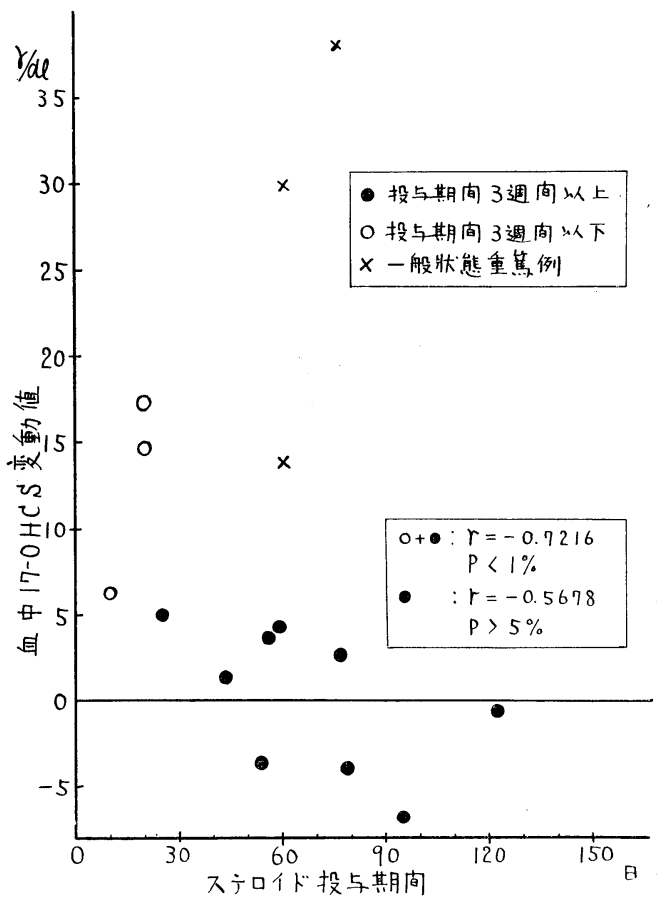


第 8 図副腎皮質ステロイド剤連続投与例に $\mathrm{AGTH}$ を投与した際の血中 17-OHCS 変動值とステ ロイド総投与量との関係

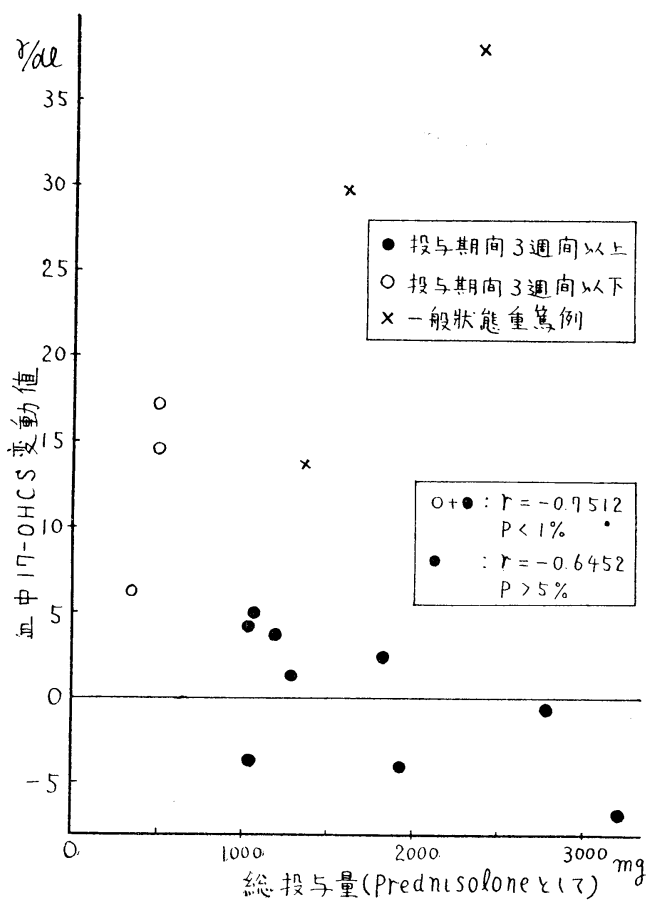

第9図 副腎皮質ステロイド剤連日投与例に $\mathrm{ACTH}$ を投与した際の血中 17-OHCS 変動值と平均 1 日投与量との関係

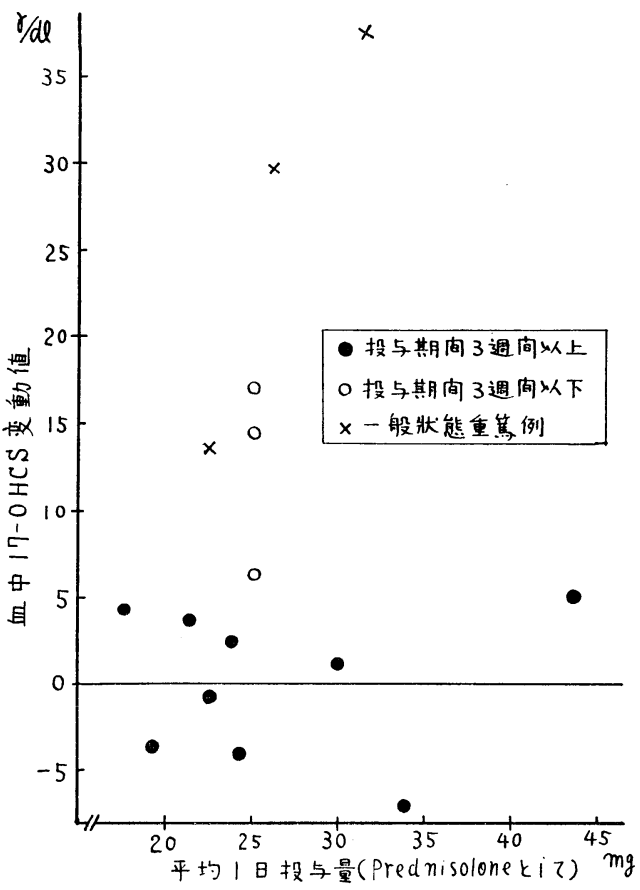

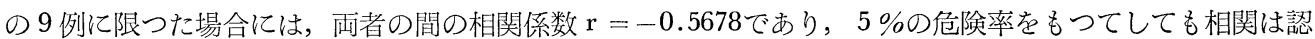
められなかつた。一般状態重篤であつた 3 例は，投与期間が夫々60日，61日及び76日でかなり長期間であつ たにも拘わらず，正常またはそれに近い増加值を示した。

総投与量と血中 17-OHCS 変動值との関係は第 8 図に示した如くであり，この場合も一般状態重篤であつ た 3 例を除いた12例では，投与量が多い程反応は低下する傾向を示し，総投与量と変動值との間の相関係数 $\mathrm{r}=-0.7512$ であり，危険率 $1 \%$ 以下で逆相関が涩められた。然し長期投与の 9 例に限つた場合には両者の

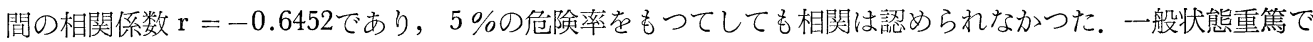
あつた 3 例では，総投与量が Prednisolone に換算して夫々 $1345 \mathrm{mg} ， 1590 \mathrm{mg}$ 及び $2385 \mathrm{mg}$ とかなり大量で あつたにも拘わらず，正常またはそれに近い増加值を示した。

この際 1 日の投与量が問題になる。そこで総投与量を投与期間で除した值，即ち平均 1 日投与量について 検討を加えた。 その最小量は $17.6 \mathrm{mg} / \mathrm{day}$ ，最大量は $43.7 \mathrm{mg} / \mathrm{day}$ で，全例における平均は $27.3 \mathrm{mg} / \mathrm{day}$ であり，ての最小量でも下垂体を抑制するに充分な量と考えられる。乙れらの各例における平均 1 日投与量 と血中 17-OHCS 変動值との間には，第 9 図に示した如く何らの相関も認められなかつた $(r=+0.0745)$.

小括

ステロイドを連日投与した例における副緊皮質予倩能には低下が認められたが，然しその程度と平均 1 日 投与量との間には有意の相関は認められず，一般状態重篤であつた 3 例を除いては，投与期間及び総投与量 との間に有意の逆相関が浔められた。然してれらの例のうち投与期関が 3 週間以上に及んだ例では投与期間 及び総投与量との間に有意の相関は認められなかつた。 
c) ACTH-Z を連続併用した際の血中 17-OHCS，尿中 17-OHCS 及び尿中 17-KS の変動

(第 2 表. 第 $10,11,12$ 図)

ステロイド連日投与中に ACTH を併用した場合には，低下した副䊆皮質機能がどの位の期間で回復する かを知る目的で, まず ACTH 試験を行なつて反応が不充分であるてとが認められた 5 例に, Dexamethasone 1.5〜 4.5mg 投与を持続しながら ACTH-Z 40単位を 5〜 7 日間筋注し，その際の血中 17-OHCS 值，尿中 17-OHCS 及び 17-KS 排泄量の変動を検索した。 その結果は第10図から明らかな如く，血中 17-OHCS 值 の反応は 5 例中 4 例では ACTH-Z 3〜 5 日間の投与で, 正常対照例に ACTH-Z を1 回投与した後の值 と同じ值に達したが，他の 1 例では 5 日目でもその反応值は正常以下であつた。尿中 17-OHCS 及び17-KS

第 2 表 副腎皮質ステロイド剤連日投与例で ACTH に対する反応不充分な例に ACTH-Z 40単位連日筋注した際の血中 17-OHCS，尿中 17-OHCS 及び 17-KS 值

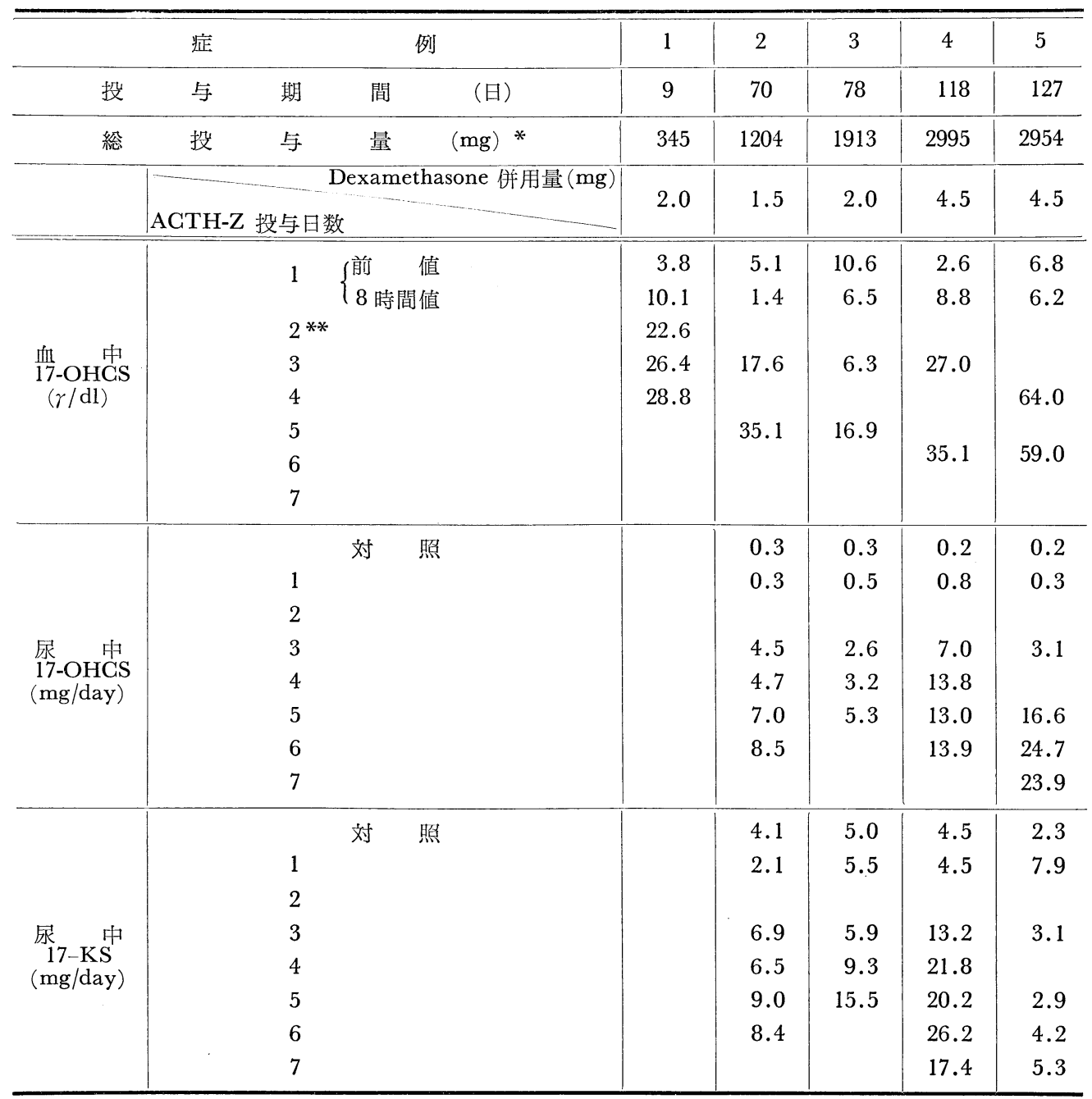

* 投与量は Prednisolone 亿換算

** 2 日目以後は AGTH-Z 筋注後 8 時間值 
第10図 副腎皮質ステロイド剤連日投与例で AGTH に対する反応不充分な例に AGTH-Z 40単位を連日筋注した際の血中17-OHCS，尿中17-OHCS及び17-KS值
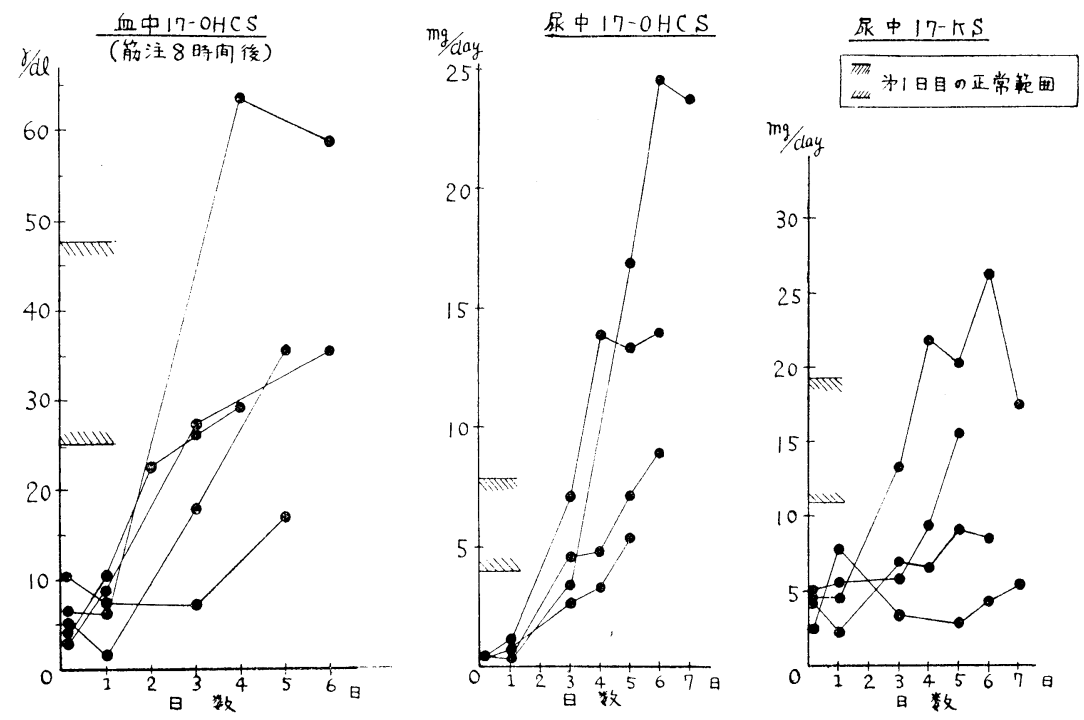

第11図副腎皮質ステロイド剂連日投与例に ACTH$\mathrm{Z}$ 在 3〜4 日間投与した際の血中 17-OHCS 值と投与期間との関係

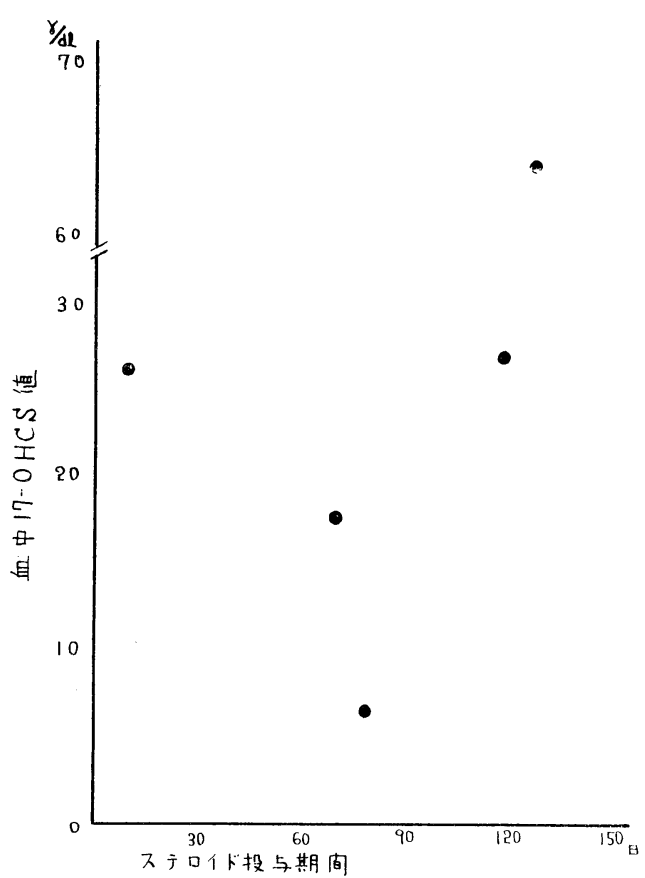

第12図 副袩皮質ステロイド剤連日投与例に ACTH-Z を 3 〜 日間投与した際の血中 17-OHCS 值 と総投与量との関係

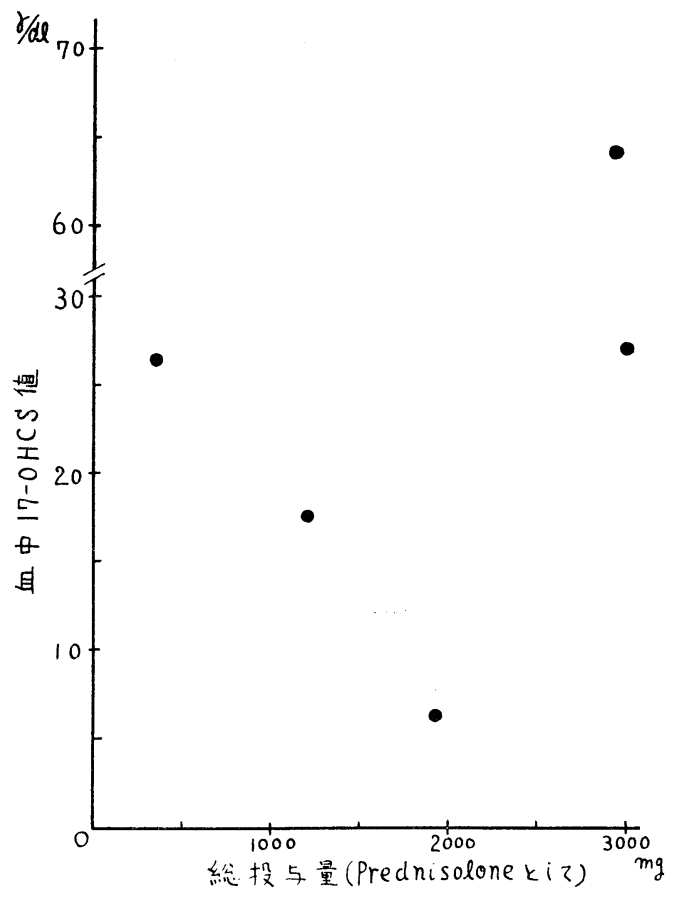


の反応も同様の傾向を示した.

投与期間と ACTH-Z 3〜4 日間投与後の血中 17-OHCS 值との関係は第11図に示した如くであり，両 者の間には何らの相関も認められなかつた。 また総投与量と AGTH-Z 3〜4 日間投与後の血中 17-OHCS 値との関係は第12戝に示した如くであり，てれも両者の間に何らの相関も認妙られなかつた。

小 括

第3表 間 歇 投 与 例

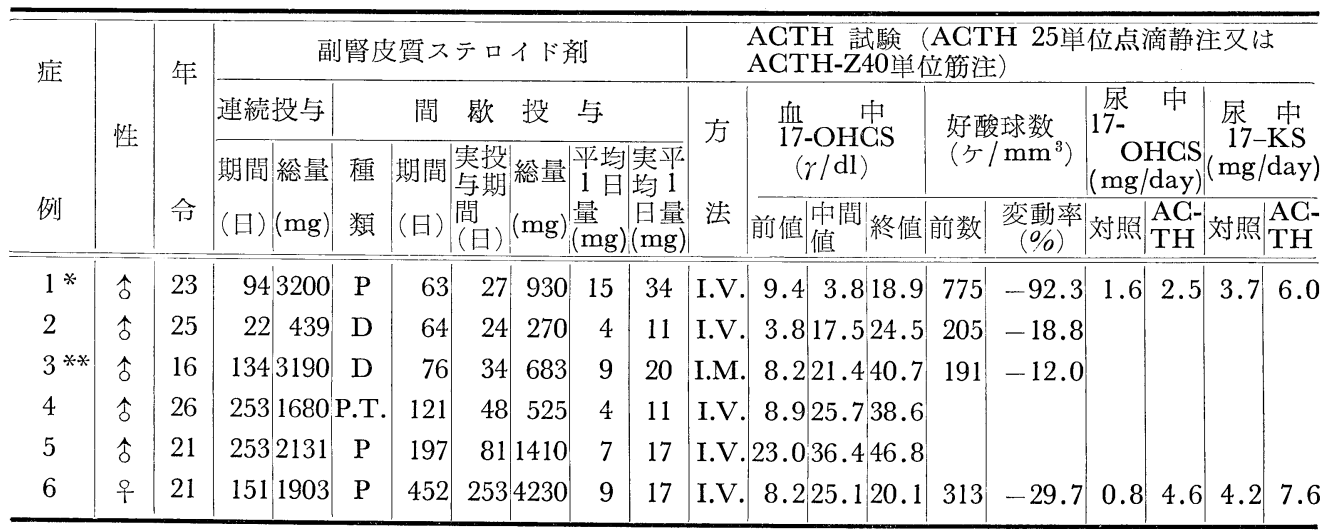

* 第 1 表症例 14 と同一例

** 第 1 表症例 15 と同一例

ステロイドを連日投与した際の ACTH に 対する皮質反応の低下は，ACTH-Z 40単位 $3 \sim 5$ 日間の投与でほぼ回復した。 ての反応 回復性と投与期間及び総投与量との間には何 らの相関も認められなかつた。

\section{2) 間歇投与例}

a) ACTH 投与による血中 17-OHCS，尿中 17-OHCS，尿中 17-KS 及び好酸球数の变

動（第 3 表. 第 $2 ， 3 ， 6 ， 13$ 図）

ステロイドを長期間間歇投与した 6 例につ いて，ACTH 試験を施行した際の血中 17OHCS 值の変動は第13図に示した如くであ り，6例中 4 例では正常の反応が認められた が，他の 2 例では軽度の反応低下がみられ た. その中の 1 例は山型の反応曲線を示した が，乙の例は投与日数の方が間歇日数より長 かつた例である。

6 例飞おける血中 17-OHCS 值の平均值は 第 2 図に示した如くであり, 前值 $10.3 \gamma / \mathrm{dl}$, 中間值 $21.7 \gamma / \mathrm{dl}$, 終值 $31.6 \gamma / \mathrm{dl}$ で正常であ つた。 またての平均增加率は, 中間值 111.2 $\%$ ，終值208.2\%で正常であつた。
第13図 副䝳皮質ステロイド剂間歇投与例に ACTH を投与した際の血中17-OHCS 值の変動

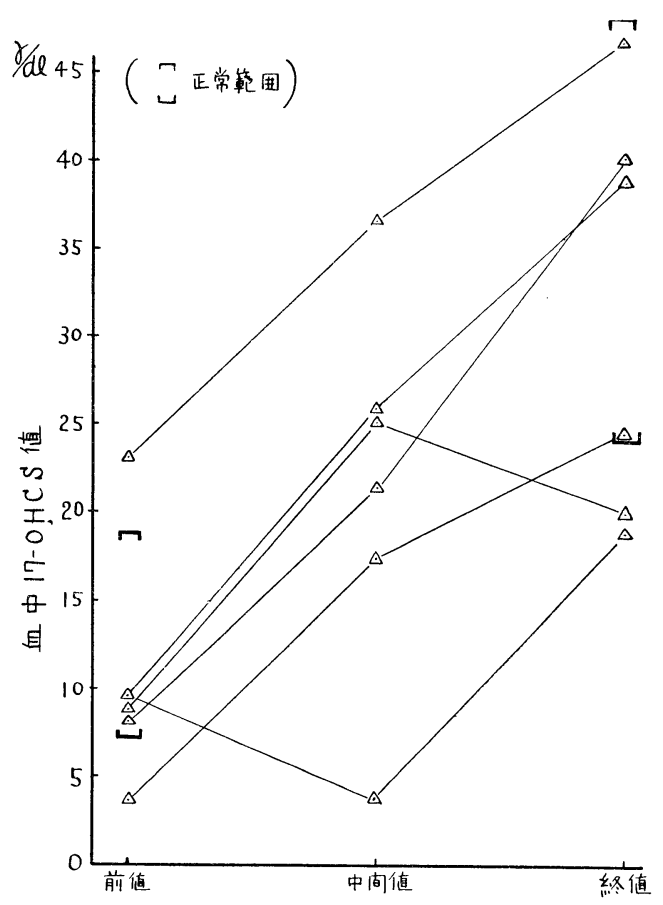


血中 17-OHCS 前值と AGTH 刺激值との関係は第3 図から明らかな如く, 前值の高低とACTH に対 する反応との間に相関は認められなかつた。

血中 17-OHCS 変動率と好酸球変動率との関係は第 6 図から明らかな如く，血中 17-OHCS が正常の反 応を示した例でも好酸球減少率が不充分な例があり，両者の間に相関は認められなかつた。

尿中 17-OHCS 及び 17-KS の AGTH に対する反応もほぼ正常であつた.

b) ACTH 投与による血中 17-OHCS 值の変動とステロイド投与期間, 総投与量及び平均 1 日投与量との関 係（第 3 表. 第 $14 ， 15 ， 16$ 図）

第14図副腎皮質ステロイド剤間歇投与例にAGTHを投与した際の血中 17-OHCS增加值と投与期間との関係

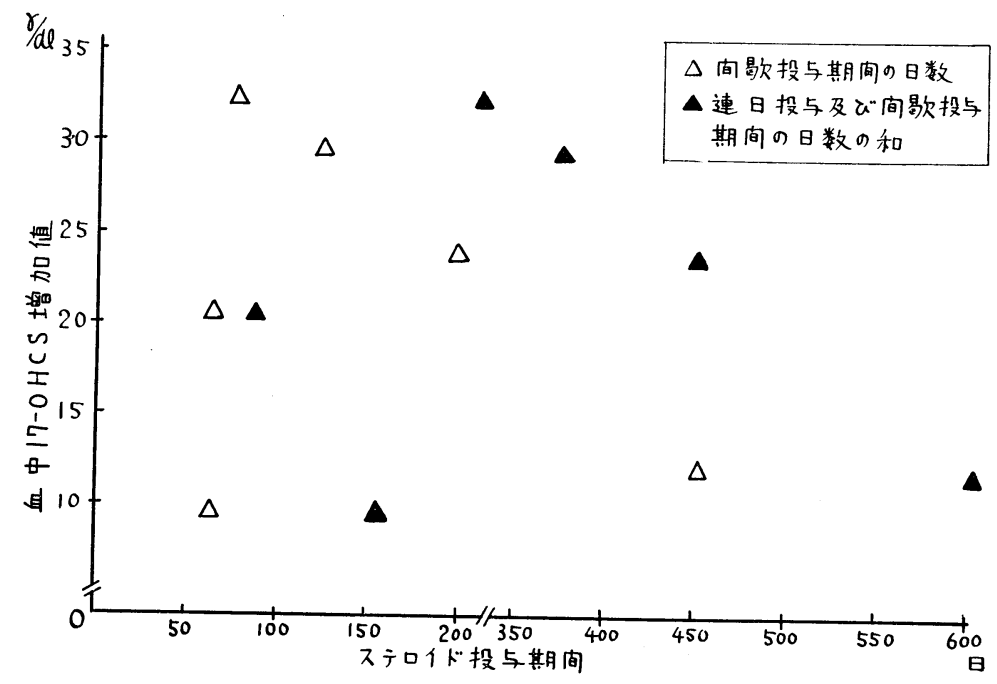

第15図副腎皮質ステロイド剤間歇投与例に ACTH を投与した際の血中 17-OHCS 増加值と総投与量との関係

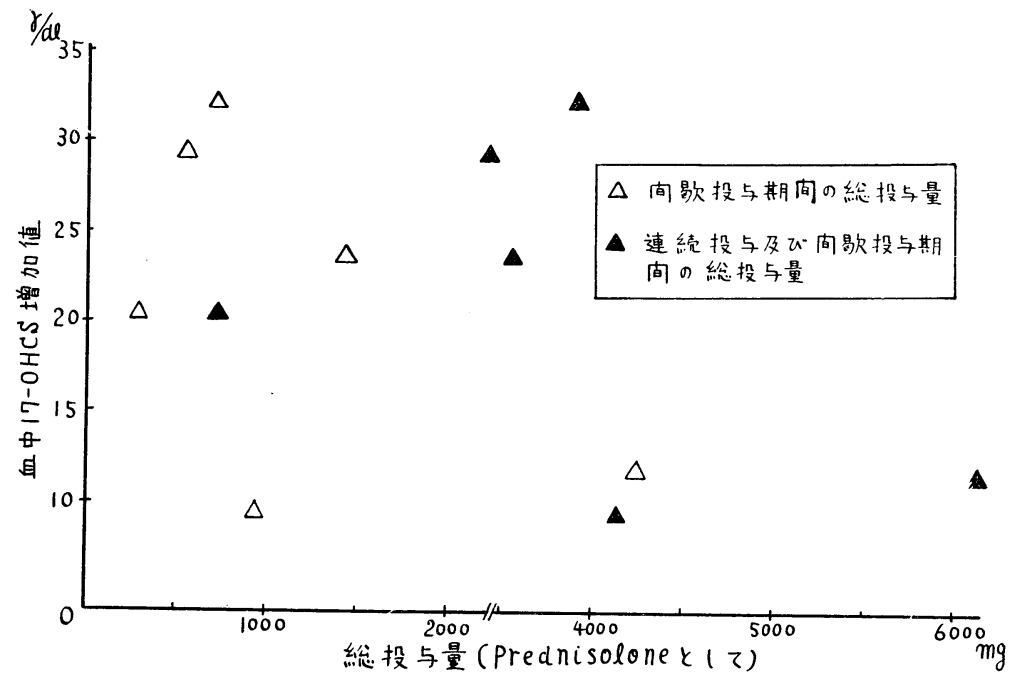

第37巻 第 10 号 
第16図 副腎皮質ステロイド剤間歇投与例にACTHを投与した際の血中

17-OHCS増加值と平均 1 日投与量との関係

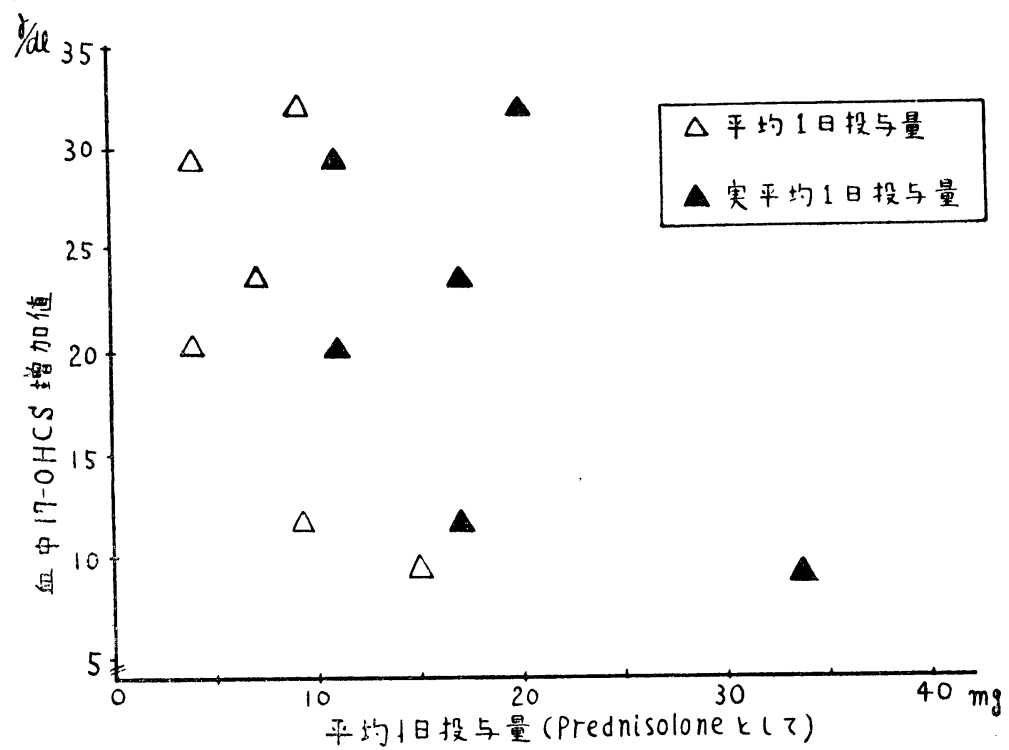

ステロイドを始め連日投与し，のち間歇投与に切換えた 6 例における ACTH 投与時の血中 17-OHCS 増加值と投与期間との関係は第14図に示した如くであり，その増加值は間歇投与期間の日数とも，連日投与 期間及び間歇投与期間の和との間にも相関を示さなかつた。 また総投与量と血中 17-OHCS 増加值との関係 は第15図に示した如くであり，両者の間に相関は認められなかつた。

間歇投与期間内の総投与量を間歇期間の日数で除した值，即ち平均 1 日投与量は $4.2 \sim 14.8 \mathrm{mg}$ ，平均 8.1 mgであり，その量が下垂体を抑制するに不充分と思われた例もあつたが，総投与量を間歇投与期間中の実 投与日数で除した值，即ち実平均 1 日投与量は11.0〜 34.4mg，平均 $18.5 \mathrm{mg}$ で，下垂体を抑制するに充分と 考えられる量であつた。乙れらの平均 1 日投与量と血中 17-OHCS 増加值との関係は第16図に示した如く であり，前述の何れの平均 1 日投与量との間にも相関は認められなかつた。

\section{第 4 章 考按}

臨床上最も特異的且つ定量的な副腎皮質予備能検查法は，ACTH を静注負荷した際の血中 17-OHCS の 変動を測定するととであるとされている ${ }^{16)}$. 私は，既に第 1 報に述べた如く，ACTH-Z 40単位筋注法に ACTH 25単位点滴静注法と同等の皮質刺激効果があるととを認めたので，本報告では ACTH-Z 筋注また は ACTH 点滴静注により，血中 17-OHCS の変動を主な指標として，ステロイド連日投与例及び間歇投 与例の皮質予備能を検索した。

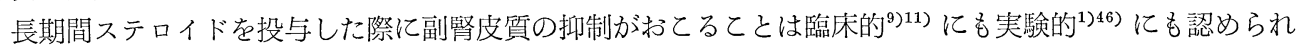
ていたが，1953年 Salassa ら ${ }^{13)}$ が Cortisone 療法中または中止後の患者に外科的手術を行なつた際，急性 副腎皮質不全を起して死亡した例を報告し，乙れが Cortisone 投与による副腎萎縮と関係があると述べて 以来，ての合併症の重要性か認識される様になり，今日なお臨床上重要な問題となつている。

この臨床症状に関係をもつ解部学的変化については, Salassa ら $\left.{ }^{13}\right)$ Cortisone 治療を行なつた剖検例で 副腎重量の有意の減少と皮質細胞の Lipoid の減少，及び下垂体好塩基細胞の顆粒の消失等の変化を認め，

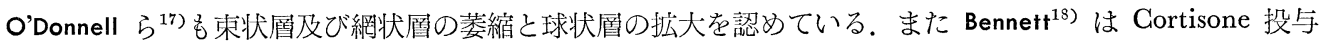


患者の剖検例で下垂体好塩基細胞の変化，及びてれとほぼ平行した皮質細胞の Lipoid の消失を認めたと述 べている. 然し Holub ら ${ }^{4)}$ は 5 例のステロイド投与患者の剖検例のうち, 下垂体の好塩基細胞に変化を認め たのは 1 例のみで，他の 4 例では正常であつたと述べている.

ステロイドを投与した際のとの様な副腎皮質の菱縮が，ステロイドの副㻉皮質に対する直接の抑制効果に よるものではなく，下垂体からの AGTH 分泌を抑制する2 次的結果であるととは，下垂体摘出動物に AGTH と Cortisone を同時に投与した場合の副緊重量が ACTH 単独投与の場合と変りなく, 更に下垂 体摘出ラッテの副腎萎縮の程度が Cortisone を投与しても変りがない(19)ととから現在広く認められている. 臨床的に $9 \alpha$-Fluorohydrocortisone または Dexamethasone を投与すると尿中 17-OHCS 排泄量が著減 し ${ }^{2021)}$ ，血中 17-OHCS 值が著明に低下する ${ }^{22)}$ とが知られている。

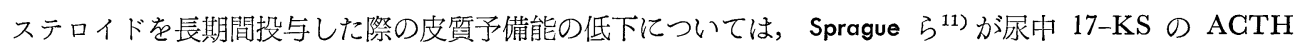
に対する反応低下を認めて以来，多くの報告がなされているが，血中 17-OHCS を指標とした報告には， Eik-Nes $~^{23)}$, Christy $ら^{24)}$, Sandberg $~^{25)}$ 及び Bierich $~^{26)}$ 等の報告がある. Christy $~^{24)}$ は 9 例の患者に おいて Prednisolone 投与前後に夫々 ACTH 点滴静注を施行し, Prednisolone 中止直後の血中 17-OHCS

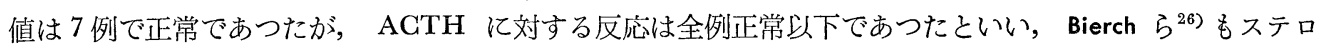
イド中止後の血中 17-OHCS 值は全例正常範囲内にあつたが, その ACTH に対する反応は全例正常以下 であつたと述べている. 私の成績では, 連日投与例16例中 7 例では血中 17-OHCS 前值は正常範囲内にあつ たが，ACTH に対する反応は一般状態重篤であつた 3 例及び短期間投与例中の 2 例を除いた10例では著明

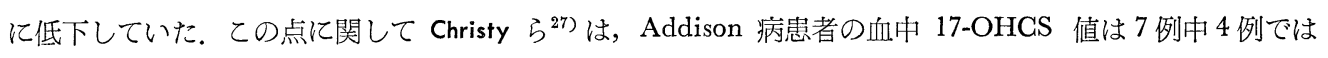
正常であつたが ACTH には全く反応を示さなかつたと述べてい。．ての様に皮質予備能は低下していても 血中 17-OHCS 值は正常に保たれている例が展々みられる。

前述の Christy $~^{24)}$ 及び Bierich $~^{26)}$ の報告は何れも ACTH 投与前後 2 回の測定であるが，私は ACTH 投与前, 中間, 及び後の 3 点の血中 17-OHCS を測定した. その成績では ACTH 投与後の終值は反応不 充分であつた例でも中間值はかなりの反応を示し, 山型の反応曲線を示した例が多くみられた。この様な反 応曲線は，私の第 1 報 47 の Addison 病及び Addison 病の疑いの 2 例でもみられた。 また同じく山型の反

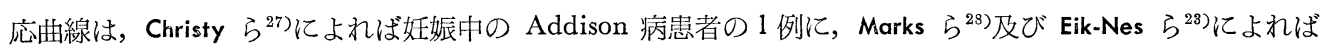
ステロイド長期投与中の各 2 例にみられたという。 私の成績及びてれらの報告から, ステロイドを長期間投 与した患者においても, その副腎皮質には或る程度の予借能が残つており, それが ACTH 刺激にある程度 反応し血中 17-OHCS 值は一時増加するが，間もなく停止し，その後急速に下降するものと推定される.

Samuels ${ }^{29}$ によると ACTH の皮質刺激作用は 1 次的作用と 2 次的作用の 2 つ分けられ，前者は既に存 在する䣼素による生合成単位に直接作用して活性を高めるもので, ACTH 投与後 2 分以内で効果か現われ 始める. 後者は生合成単位の数の増加, 即ち究極的には微視的または巨視的の肥大の現象を生ぜしめるもの で，投与後 $2 \sim 4$ 時間後にはじめてその効果が現われるものであるという．ての説により山型反応を説明す ると，ステロイド長期投与例の副整皮質には或る程度の醭素生合成単位が残つており, ACTH の 1 次的作 用により Cortisol が血中に分泌され血中 17-OHCS 值は一時上昇するが， その生合成単位の数の増加機構 に障害があり ACTH の 2 次的作用は発現されにくく，その為分泌が著減して血中 17-OHCS 值は下降す るものと推定される. 若しての説明が妥当であるならば，ACTH 投与による血中 17-OHCS の反応を 3 点 でみるととは副腎皮質機能の詳細を窅うに有用な方法であるとい光る。事実てれを証左すると思われる報告 がある. 即ち甲状腺機能六進症舁者における皮質予供能について Felber $ら^{30}$ は ACTH 点滴静注を連続 2 日間施行した際の永中 17-OHCS 排泄量が正常とは逆に第 2 日目に第 1 日目より低下するのを認め本症で は皮質予備能の低下があるととを明らかにした。一方 Mikulaj ら ${ }^{31)}$ 同しくく状腺機能充進症患者にACTH の少量を 6 時閔点滴静注した際の血中 17-OHCS が，3時問值ではほぼ正常に增加しているが 6 時間值で は正常とは逆に低下し山型曲線を示し予䟮能低下のあることを劲めている。

ステロイド剤長期間投与中の患者の副緊皮買の ACTH に対する反応に個体差があるととは既に Sprague 
$ら^{11)}$ も認めており, Vermeulen ${ }^{322}$ も13例中 2 例が正常の反応を示したと報告している. しかしその理由につ いての考按はなされていない，私の成績ではステロイド長期間投与例 13 例中 3 例は前述の如くステロイド投 与中，発熱，腹水及び浮腫，または高度の呼吸困難を訴え一般状態重篤であつた例である，ての中呼吸困難 の強かつた 1 例では，剖検により副婜皮質が菱縮していなかつたてとが確涩されている ${ }^{33}$. Stress が加わる と血中 17-OHCS が上㫒するてとは既に認められている5374. 然しその直接の原团については不明な点が多 い. Sayers ${ }^{2}$ はその実験研究の結果から，Stress の際には末梢組織における副婜皮質ステロイドの代謝また は利用が元進する為，血中ステロイド濃度が低下し，その結果下垂体が刺激されて ACTH 分泌か増加する

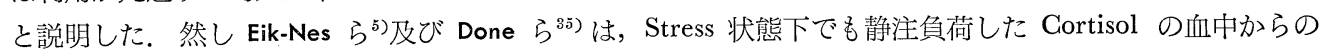
消失速度は正常と比へて无進していないととを認め，更に Dougherty ら ${ }^{36)}$ は Cortisol 4-G' ${ }^{14}$ を用いた実験 的研究により，卵アルブミン皮下注射による炎症組織中のステロイド量は正常組織中のそれより多いが，血 中からの消失速度は正常であつたと述べている，ての様に Sayers の説は Stress 状態下の急速な ACTH 分泌機序としては現在一般に否定的である。一方視床下部が ACTH 分泌に深い関係を有しているてとは Harris $^{37)}$ 及び Porter ${ }^{38)}$ により報告されて以来現在広く認められており, 更に大脸辺縁系が ACTH 分泌に 関係しているととが最近知られてきて，精神的 Stress が下垂体副腎皮質系を賦活することは，実験的 ${ }^{399}$ 及 び臨床的研究 ${ }^{40) 41}$ によつて一般に認められている事実である。また内藏神経刺激が副腎皮質ホルモン分泌を 促進するという報告(6)もあり，Stress 時の下垂体副整皮質系の反応は複雑である。然し Feed-back 機構は 少なくとも Stress 状態下では発現されず，副腎皮質ホルモンの血中濃度とは関係なく，精神的 Stress また は組織の破囬による肉体的 Stress が下垂体を介し，或いは一部は神経を介して副腎皮質ホルモン分泌を刺 激すると推定される。私の一般状態重篤であつた 3 例も，精神的または肉体的 Stress が下垂体を介しまた 一部は神経を介して副婜皮質を刺激していた為，ステロイドを長期間投与したにも拘わらず副腎皮質の抑制 が起らなかつたものと考光られる。

ステロイドの投与期間または投与量と副婜皮質機能低下の程度との関係については，未だ一致した意見を みない. Ingle ら ${ }^{1}$ は既に実験的研究から，副筱の菱縮はステロイド投与期間に関係するが，投与期間が或る 程度以上長くなると両者の間に関係がないととを認めている。 Christy ら ${ }^{24)}$ は臨床的に血中 17-OHCS の ACTH に対する反応から，ステロイドの皮質抑制は 1 日の投与量よりむしろ投与期間に関係すると述へ， Carreon $~^{42)}$ ，Bierich $~^{26)}$ も同意見を記載している。一方 Vermeulen ${ }^{32)}$ は尿中 17-OHCS を指標とした臨 床的研究から，ステロイドの投与期間及び投与量と皮質の ACTH に対する反応との間には有意の相関は 認められなかつたと述へ，Meakin ら ${ }^{43}$ も同様の意見を述べている。私の成績では，3 週間以下の短期投与 例を含めた場合は投与期間及び総投与量と皮質反応性との間に有意の相関を認めたが， 3 週間以上の長期投 与例では両者の間に有意の相関は認められず，1 日投与量と皮質反応との間には全く関係が認められなかつ た.

ステロイド投与後の副腎皮質機能低下が ACTH 投与により回復するてとは知られているが，ての回復が どの位の期間を要するかについては定説をみない. Vermeulen ${ }^{32)}$ はステロイド投与中止後 AGTH-Z 20単位 を 5 日間投与した際の尿中 17-OHCS の反応から, 皮質機能の回復は ACTH の投与期間及び投与量とは関 係なく，13例中 9 例は ACTH 投与 5 日目にも未だ回復しなかつたと記載している。一方 Eik-Nes ら ${ }^{23}$ は Cortisone 長期投与の 2 例に ACTH 6 時間点滴静注を施行した際の血中 17-OHCS の反応から, ACTH 投与 3 日目に何れも正常の反応を得たと述べている. Christy Gel 20〜40単位を連日投与した結果，1例を除き，血中 17-OHCS の反応は $3 \sim 10$ 日間で正常に回復する てとを認めている。またての場合の回復性遅延因子としてはステロイド 1 日投与量よりも投与期間が重要で あると述べている. Dexamethasone 投与中に ACTH-Z 40単位を併用した私の例の血中 17-OHCS の反応 では，5例中 4 例は $3 \sim 5$ 日間で正常に回復したが，1 例では 5 日後にも回復しなかつた。またその反応回 復性と投与期間及び総投与量との間には関係が認められなかつた。

この様にステロイド長期間投与後の副堅皮質の機能低下は ACTH 投与により回復するが，ての回復が 
ACTH 中止後も続くか否かについては議論がある. Carreon ら ${ }^{12}$ は，ステロイド長期間投与後に ACTHGel 40単位を 5 〜 日間投与すると減少していた尿中 17-OHCS 排泄量は正常以上に增加してくるがACTH を中止すると再び減少し正常以下になるてとを認め，乙の際の ACTH 投与はあまり有意義でないと述べて いる。乙てで問題になるのはステロイド投与による下垂体の抑制の程度及びその回復であるが，最近 Holub ら ${ }^{4)}$ はステロイド長期投与患者の剖検例で下垂体 ACTH 濃度の平均值は正常対照群のそれと比べて低下し ていないととを認め，また SU-4885 を投与した祭の尿中 17-KGS の增加も4例中 3 例では正常であつた と述べており，Meakin ら ${ }^{48}$ もステロイド長期投与患者に AGTH 試験及び SU-4885 試験を行なつた成績 から，下垂体の抑制は副粲皮質の抑制より軽度であり，また回復も速かであると述へている。また Marksら ${ }^{28)}$ は，手術による血中 17-OHCS 增加反応はステロイド長期投与患者では低下していたが，ACTH-Gel 長 期投与患者では正常であつたと述べており，ACTH 投与例では Stress に対する下垂体 ACTH 分泌能は 正常に保たれていると考朰られる。実験的にも正常ラッテにACTH を投与すると内因性ステロイドの分 泌が増加するにも拘わらず,下垂体 ACTH 濃度も高まるととが涊められており ${ }^{44)}$, またラッテに Cortisone とACTH とを併用した際には, Cortisone 単独投与時と比べて下垂体 ACTH 浱度の低下は軽度であり, 且つ Stress を加えた際の下垂体 ACTH 合量の減少率はほほ正常に近いととが知られている゙3. Young ${ }^{45)}$ は長期 Cortisone 投与中，ACTH を間歇的に併用するととにより，副婜皮質の ACTH に対する反応を正 常に保持出来たと述べている. 以上の考察からステロイド投与時の下垂体の抑制は比較的軽度であり, ACTH の併用またはステロイド中止後の ACTH 投与は下垂体副腎皮質機能低下を防止し，急性副腎皮質 不全の予防注有用であると考光られる。

1955年 Longe らは，下垂体及び副腎皮質の抑制を避け得るステロイド投与法として 間歇投与法を提唱し たが，間歇投与例と連日投与例について ACTH に対する副婜皮質反応を比較検討した報告は極めて少な い. Bierich $弓^{26)}$ は週 4 日間投与，3 日間休薬の間歇投与例では，ACTH 刺激による血中 17-OHCS の增 加がほぼ正常であるととを認め, 週 4 日間投与では下垂体副腎皮質の機能低下を起すに期間が短か過ぎるこ とによると考えている。この点に関し，Winter ら ${ }^{46)}$ はラッテに Cortisone を投与した際の副腎皮質の萎縮 は投与開始 5 日目から顕著となり，また投与中止後 4 日目で組織学的に既に回復するととを認めたといい, Bennett ${ }^{18)}$ は Cortisone 投与 5 日間以内の 9 例の剖検例では, 副腎重量は全例正常範囲内にあつたと述べて いる. また Calkins ${ }^{10)}$ は長期ステロイド投与患者の 3 例で投与中止後 3 日間は皮質不全の症状及び代謝異 常を示したが，4 日目には内因性皮質ステロイド産生の証拠を認めたと述べている。乙れらの考察から 3 4 日間のステロイド投与では下垂体副腎皮質の抑制は不充分であり，またその程度の軽度の抑制は $3 \sim 4$ 日 の間歇期間内に回復し得ると考えられる.

私の成績では間歇投与を行なつた 6 例中 4 例は ACTH に対し全く正常の反応を示し, 他の 2 例もほほ正 常の反応を示した。しかも全例間歇投与法を行なう前に長期間連日投与を行なつていた例である.

間歇投与法と連日投与法の臨床効果の差異については全く不明であり，また間歇投与法の適応疾患は現在 の所限られている，然しステロイド療法の最も重要な副作用である下垂体副腎皮質系の抑制を避け得るとい う点で, 間歇投与法は優れた方法と考光られる。

\section{第 5 章＼cjkstart総括並びに結論}

ステロイドを連日投与または間歇投与した際の副婜皮質予備能を検索する目的で，ステロイド連日投与例 15例及び間歇投与例 6 例に，血中 17-OHCS を主な指標として ACTH 試験を施行した。更に連日投与例 5 例に ACTH-Z 40単位を 5〜 7 日間投与して，乙れによる皮質反応の回復性を観察した.

1） 3 週間以上の長期にわたる連日投与例12例中 9 例では，ACTH に対する反応が著明に低下していた が，他の 3 例は正常の反応を示した。 ての 3 例は何れも一般状㮩が重篤な例であつた.

2) ACTH に対する反応が低下していた 9 例中の 6 例では，血中 17-OHCS の中間值が前值及び終值よ り高く山型の反応曲線を示した。 
3) 短期投与例 3 例中 2 例は ACTH 飞刘し正常の反応を示したが，他の 1 例は正常以下であつた.

4) 連日投与例15例における血中 17-OHCS 前值は，7例で正常範国にあつた。乙れら15例における ACTH に対する反店と前值との間には, 相関は認められなかつた。

5) ACTH 投与による血中 17-OHCS 変動率と好酸球変動率との間には, 相関は認められなかつた。

6) 連日投与例15例中一般状態重篤であつた 3 例を除いた12例では，ACTH に対する反応と投与期間及 び総投与量との間に有意の逆相関か想められたが，そのうちの長期投与例 9 例では両者の間に有意の相関は 認められなかつた。 また平均 1 日投与量との間には，全く相関か認められなかつた。

7）連日投与例中の 5 例に ACTH-Z を連日投与したとてろ，低下していた皮質反応は $3 \sim 5$ 日間でほぼ 回復した。この反応回復性とステロイドの投与期間及び総投与量との間には，全く相関が認められなかつ た.

8) 連日投与から間歇投与に移行した 6 例中 4 例では AGTH に対し全く正常の反応を示したが，他の 2 例では反応はやや低下していた。 ての ACTH 亿対する反応とステロイドの投与期間, 総投与量及び平均 1 日投与量との間には全く相関は認められなかつた。

以上の結果から，ステロイドを長期間連日投与すると一般に 2 次的副腎皮質機能低下を起すが，精神的ま たは肉体的 Stress が加わつた例ではてれが起り難いてと，また開歇投与法は 2 次的副緊皮質機能低下が避 け得るという点で, 連日投与法より優れていることが認められた。更にステロイド連日投与中止時にACTH$\mathrm{Z}$ 在数日間投与寸ることは，急性副腎皮質不全の予防に有用であると推定された。

本論文の要旨は，第33回日本内分泌学会総会に打いて発表した。

稿总終るにあたり, 終始御恩切な御指導, 御校閲を賜わつた恩们鳥哂教授に深甚なる謝意を表します。

な抢，乙の研究に使用した ACTH-Z は第一製薬株式会社上り贈与されたものであり，乙てに感謝の意 表表します。.

\section{文献}

1) Ingle, D.J. et al. : Anatom. Rec., $71: 363,1938$.

3) Holub, D.A. et al. : J. Clin. Invest., $38: 291,1959$.
2) Sayers, G. : Physiol. Rev., $30: 241,1950$.

4) Holub, D.A. et al. : J. Clin. Endocrinol., $19: 1540,1959$.

5) Eik-Nes, K. \& L. T. Samuels : Endocrinol., $63: 82,1958$.

6) 伊藤德治 : 日内会誌, $47: 333$, 昭 33 . 7) 吉田 尚: 日内分泌誌, $35: 57$, 昭34.

8) Forsham, P.H. et al. : J. Clin. Invest., $29: 812,1950$.

9) Mc Intosh, H.W. \& C.B. Holmes : Lancet, 261 : 1061, 1951. 10) Calkins, E. et al. : J. Clin. Endocrinol,. $15: 856,1955 . \quad 11$ 1) Sprague, R.G. et al. : Arch. Int. Med., $85:$ 199, 1950.

12) Fraser, C.G. et al. : J.A.M.A., $149: 1542,1952$.

13) Salassa, R.M. et al. : J.A.M. A., $152: 1509,1953$.

14) Bayliss, R.I.S. : Brit. M. J., $2: 935,1958$.

15) Stevens, A.E. : Lancet, II : 234, 1960.

16) Eik-Nes, K. et al. : J. Clin. Invest., $33: 1502$,

1954.

17) O'Donnell, W.M. et al. : Arch. Int. Med., $88: 28,1951$.

18) Bennett, W.A. : J.

Bone \& Joint Surg., $36: 867,1954$.

19) Stebbins, R.B. : Endocrinol., $49: 671,1951$.

20)

Goldfien, A. et al. : J. Clin. Endocrinol., $15: 850,1955$.

21) Goldfien, A. et al. : New England J. Med., 252 : 415, 1955. 22) Bunim, J.J. et al. : Arthritis \& Rheumatism, 1:313, 1958. 23) Eik-Nes, K. et al. : J. Clin. Endocrinol., $15: 13,1955$.

24) Christy, N.P. et al. : J. Clin. Endocrinol., $16:$ 1059, 1956.

25) Sandberg, A.A. et al. : J. Lab. \& Clin. Med., $50: 286,1957$. 26) Bierich, J.R. et al. : Acta Endocrinol., $31: 40,1959$.

27) Christy, N.P. et al. : J. Clin. Invest., $34: 899,1955$.

28) Marks, L.J. et al. : J. Clin. Endocrinol., $19:$ 1458, 1959.

29) Samuels, L.T. : 内分泌子代謝 $2:(3) ， 165$, 眧35.

30) Felber, J.-P. et al. : J. Clin. Endocrinol., $19: 895$, 1959.

31) Mikulaj, L. \& S. Nemeth : J. Clin. Endocrinol., $18: 539,1958$.

32) Vermeulen, 
A. : Acta Endocrinol., $28: 321,1958$.

Klein, R. et al. : J. Pediat., $43:$ 385, 1953.

33) 剖検例をめぐつて : 最新医学, $15: 2465$, 吸 35 $16: 921,1956$.

36) Dougherty, T.F. et al. : Endocrinol., 62 : 455, 1958.

35) Done, A.K. \& V.C. Kelley: J. Clin. Endocrinol., : Ciba Found. Colloqia Endocrinol., 4 : 106, 1952.

38) Porter, R.W. : Amer. J. Physiol., 169 : 629, 1952.

39) Mason, J.W. : Endocrinol., $60: 741,1957$.

40) Persky, H. et al. : Arch. Neurol. \& Psychiat., 76 : 549, 1956.

41) Price, D.B. et al. : Arch. Neurol. \& Psychiat., 77 : 646, 1957. 42) Carreon, G.G. et al. : J. Lab. \& Clin. Med., $56:$ 235, 1960.

43) Meakin, J.W. et al. : Amer. J. Med., $29: 459,1960$. 44) Kitay, J.I. et al. : Proc. Soc. Exper. Biol. \& Med., 97 : 165, 1958. 45) Young, I.!. et al. : Arch. Int. Med., $100: 1,1957$.

46) Winter, C.A. et al. : Endocrinol., $47: 60,1950$.

47) 渋川直次 : 日内分泌誌, $37: 992,1961$. 